\title{
Meta-analysis of corn plants, green fodder (ensilage), and silages of different types of maize hybrids used in experimental conditions in Brazil
}

\section{Metanálise sobre o cultivo de milho, forragem verde (ensilagem) e silagens de diferentes tipos de híbridos de milho produzidos em condições experimentais brasileiras}

\section{João Pedro Velho ${ }^{1 *}$; Pagiel Bernardi Zardin²; Clóves Cabreira Jobim³; Ione Maria Pereira Haygert-Velho ${ }^{4}$; Dileta Regina Moro Alessio ${ }^{5}$; Ênio Giotto ${ }^{6}$; Gabriel Menegazzi da Conceição ${ }^{7}$; Cássio Rodrigo Gehrke ${ }^{8}$}

\section{Highlights:}

The chemical compositions of maize hybrids were evaluated using a meta-analysis.

Maize hybrid types (simple, double, or triple) differed mainly in grain production.

Silage processes are often not conducted in an ideal way.

Losses during the ensiling process minimize differences related to hybrid types.

Crop data should be evaluated completely for effective comparisons of hybrid types.

\begin{abstract}
The objective of this study was to conduct a meta-analysis of scientific publications from January 1994 to December 2014, to evaluate the chemical composition of corn plants, green forage, and silages of three different types of maize hybrids (simple, double, and triple) used in experimental conditions in Brazil. The sub-bases Corn Cultivation and Green Fodder were composed of 49 experiments, consisting of 481 treatments, and the sub-base Silage consisted of 24 studies composed of 163 treatments, involving 478 silos. In the Corn Cultivation sub-base, the variables of spacing, plant height, grain yield, organic matter content, and total carbohydrates of maize silage differed $(\mathrm{P}<0.05)$ according to the hybrid type. The number of corn plants per hectare, number of spikes per plant, and the levels of neutral detergent fiber, acid detergent fiber, hemicellulose, and lignin did not differ $(\mathrm{P}>0.05)$ according to the hybrid type. In the Green Forage sub-base (ensilage), the main difference $(\mathrm{P}<0.05)$ was regarding the in vitro dry matter digestibility, whereby the triple hybrids $(59.38 \%)$ had lower values than the simple $(73.05 \%)$ and
\end{abstract}

\footnotetext{
1 Prof. Associado, Departamento de Zootecnia e Ciências Biológicas, Universidade Federal de Santa Maria, UFSM, Campus de Palmeira das Missões, Palmeira das Missões, RS, Brasil. E-mail: velhojp@ufsm.br

2 Zootecnista, Estância Santa Marta, São Borja, RS, Brasil. E-mail: pagiel zardin@hotmail.com

3 Prof. Titular, Departamento de Zootecnia, Universidade Estadual de Maringá, UEM, Maringá, PR, Brasil. E-mail: ccjobim@, uem.br

4 Prof ${ }^{a}$ Adjunto, Departamento de Zootecnia e Ciências Biológicas, UFSM, Campus de Palmeira das Missões, Palmeira das Missões, RS, Brasil. E-mail: ione.h.velho@ufsm.br

5 Prof ${ }^{a}$, Centro Universitário Leonardo da Vinci, UNIASSELVI, Indaial, SC, Brasil. E-mail: alessiodrm@gmail.com

6 Prof. Titular, Departamento de Engenharia Rural, UFSM, Campus de Santa Maria, Santa Maria, RS, Brasil. E-mail: eniogiotto@ gmail.com

7 Discente, Universidad de la República Uruguay, UDELAR, Paysandú, Uruguay. E-mail: gmenegazzi@fagro.edu.br

8 Discente, Curso de Graduação em Zootecnia, UFSM, Campus de Palmeira das Missões, Palmeira das Missões, RS, Brasil. E-mail: gehrkecassio@hotmail.com

* Author for correspondence
} 
double (72.74\%) hybrids. In the Silage sub-base, the variables of organic matter, total carbohydrates, cellulose, in vitro dry matter digestibility, and $\mathrm{pH}$ differed $(\mathrm{P}<0.05)$ according to the hybrid type. While the variables dry matter, non-fibrous carbohydrates, neutral detergent fiber, acid detergent fiber, hemicellulose, lignin, total digestible nutrients, ethereal extract, crude protein, and ammonium nitrogen did not differ $(\mathrm{P}>0.05)$ according to the hybrid type. The variability in the determination of parameters, such as dry matter yield, dry matter content, and non-fibrous carbohydrates of corn silage, and the non-determination of the starch content demonstrated that the chemical compositions of Brazilian corn silage have not yet been fully clarified. The types of maize hybrids (simple, double, and/or triple) mainly differ in terms of grain production. In many situations, the silage processes are not conducted in an ideal way, and the differences as a function of the maize plants (type of hybrid) are minimized due to losses during the ensiling process.

Key words: Carbohydrate. Corn grain. Double hybrid. Simple hybrid. Triple hybrid. Zea mays.

\section{Resumo}

Objetivou-se desenvolver uma metanálise com o intuito de avaliar a composição química de plantas de milho, forragem verde (ensilagem) e de silagens de milho, em função, dos diferentes tipos de híbridos (simples, duplo e triplo) utilizados em condições experimentais no Brasil. Buscou-se artigos científicos publicados entre janeiro de 1994 a dezembro de 2014. As sub-bases denominadas Cultivo de Milho e Forragem Verde são compostas por 49 experimentos, constituídos de 481 tratamentos e a sub-base Silagem é constituída por 24 trabalhos compostos por 163 tratamentos, envolvendo 478 silos. Na subbase Cultivo de Milho as variáveis espaçamento entrelinhas, altura de plantas, produção de grãos, teor de matéria orgânica e carboidratos totais da silagem de milho diferiram $(\mathrm{P}<0,05)$, em função, do tipo de híbrido. O número de plantas de milho por hectare, número de espigas por planta e os teores de fibra em detergente neutro, fibra em detergente ácido, hemicelulose e lignina não apresentaram diferença $(\mathrm{P}>$ $0,05)$ em relação ao tipo de híbrido. Na sub-base Forragem Verde (ensilagem) a principal diferença $(\mathrm{P}<$ $0,05)$ foi em relação a digestibilidade in vitro da matéria seca, de modo que os híbridos triplos $(59,38 \%)$, foram inferiores aos simples $(73,05 \%)$ e duplos $(72,74 \%)$. Na sub-base Silagem as variáveis matéria orgânica, carboidratos totais, celulose, digestibilidade in vitro da matéria seca e $\mathrm{pH}$ diferiram $(\mathrm{P}<0,05)$, em função, do tipo de híbrido. Enquanto as variáveis matéria seca, carboidratos não-fibrosos, fibra em detergente neutro, fibra em detergente ácido, hemicelulose, lignina, nutrientes digestíveis totais, extrato etéreo, proteína bruta e nitrogênio amoniacal não apresentaram diferença $(\mathrm{P}>0,05)$ em relação ao tipo de híbrido. A variabilidade na determinação de parâmetros como produção de matéria seca, teor de matéria seca e de carboidratos não fibrosos da silagem de milho e, ainda a não determinação do teor de amido demonstram que a composição bromatológica da silagem de milho brasileira é incompleta. Os tipos de híbridos de milho (simples, duplo e/ou triplo) são diferentes principalmente quanto a produção de grãos. Em muitas situações, os processos de ensilagem não são conduzidos de forma ideal, e as diferenças em função das plantas de milho (tipo de híbrido) acabam sendo minimizadas, em função, das perdas ocorridas durante o processo de ensilagem.

Palavras-chave: Carboidratos. Grão de milho. Híbrido duplo. Híbrido simples. Híbrido triplo. Zea mays.

\section{Introduction}

Corn plant silage is recognized as one of the main bulks used in the feeding and nutrition of dairy cows (Capper, Cady, \& Bauman, 2009; Ferraretto, Shaver, \& Luck, 2018; National Research Council [NRC], 2001) and beef cattle in feedlots in the United
States of America (Capper, 2011; NRC, 2016). Corn silage is used as a feed, mainly because it provides quality non-fibrous carbohydrates and fermentable fiber to ruminal microorganisms. Thus, domestic animals fed corn silage and concentrated nutrients are able to achieve performances compatible with their genetic potentials. 
Driehuis, Wilkinson, Jiang, Ogunade and Adesogan (2018) highlighted another advantage of corn silage, provided that the basic silage process is followed: it serves as a safe food for animals and as well as for the human populations that will consume the meat, milk, and derived products. For the above reasons, among others, corn silage has been widely used in ruminant production systems in Brazil (Bernardes \& Rêgo, 2014; M. S. J. Silva, Jobim, Poppi, Tres, \& Osmari, 2015). Therefore, numerous scientific studies (Hentz et al., 2017; Krüger, Jobim, Carvalho, \& Moro, 2017; Oliveira, Bueno, Leão, Neumann, \& Jobim, 2018; Robinson, Swanepoel, Heguy, Price, \& Meyer, 2016; Wei, Chen, Wei, Geng, \& Yan, 2018; Weiss, 2019) have assessed ways to improve the chemical composition, voluntary intake, and nutritional value, as well as to reduce losses during the silage process and also during the use phase.

Continuous improvements in the total dry matter (DM) productivity and advances in the nutritional quality of whole-plant corn silage are achieved through hybrid maize breeding programs (Ferraretto et al., 2018). Heterosis and the use of hybrids are the main causes of increases in maize productivity (Costa, Souza, Lima, \& Cardoso, 2010). Simple hybrids are produced by crossing two pure lines with the aim of producing hybrid lines with greater productive potential and are, thus, destined for high technology systems. Triple hybrids, produced by crossing a pure line and a simple hybrid, are recommended for use in medium to high technology systems. Double hybrids are produced by crossing two simple hybrids and have a lower productive potential, and are thus recommended for use in medium technology systems (Araújo et al., 2016; Emygdio, Ignaczak, \& Cargnelutti, 2007; Rotili, Afférri, Peluzio, Carvalho, \& Santos, 2014).

Most corn silage experiments are conducted using a completely randomized block design and factorial arrangements. When animals are incorporated in the evaluations, they can also be delineated as cross-over or Latin square designs.
Therefore, the applications of the conclusions are generally limited to similar experimental conditions (Sauvant, Schmidely, Daudin, \& Stpierre, 2008). One way to formulate broader inferences is through a scientific systematization, such as a meta-analysis (Lovatto, Lehnen, Andretta, Carvalho, \& Hauschild, 2007). Meta-analyses can be used to facilitate rapid progress in science, to quantifying what is known, and to identify what is not yet known (Gurevitch, Koricheva, Nakagawa, \& Stewart, 2018).

In the international literature, several metaanalysis studies have been conducted on corn silage (Ferraretto \& Shaver, 2015; Hollmann, Allen, \& Beede, 2011; Kleinschmit \& Kung, 2006; Phuong, Friggens, Boer, \& Schmidely, 2013; Nasrollahi, Imani, \& Zebeli, 2015) to determine the factors that interfere with the composition and quality of the silage produced. However, much of the information contained in these previous publications cannot be extrapolated to the Brazilian conditions because of vast differences, for example, in weather, soil fertility, and the characteristics of maize hybrids. Information on the type and quality of the canvas (cover film), silo dimensions, particle size, and particle treatment can be extrapolated, provided that the same conditions can be achieved.

Thus, in the present study, we used a metaanalysis of Brazilian data to clarify the types of maize hybrids that are cultivated by researchers and used in experimental conditions in Brazil. We evaluated the chemical composition of corn plants, green forage, and silages of different types of maize hybrids (simple, double, and triple).

\section{Materials and Methods}

\section{Formation of the database}

To create the database 'Types of Hybrids', an electronic search was conducted using 'corn silage' as the keyword to identify relevant and suitable scientific articles in the public domain using the Scientific Electronic Library Online (SciELO), the 
Coordenação de Aperfeiçoamento de Pessoal de Nível Superior (CAPES) periodicals portal, and Google Scholar. The initial selection of the articles was based on the abstracts, and specific experiments on corn silage were considered for inclusion in the database if they involved simple, double, or triple types of hybrids.

All articles were read for subsequent tabulation of the data in an Excel spreadsheet, following the premises indicated by Lovatto et al. (2007). Due to the diversity of the data published in the periodicals, it was necessary to divide the base denominated by hybrid type into three data sub-bases, as follows: 'Corn Cultivation' (i.e., row spacing, number of plants ha $^{-1}$, number of spikes plant ${ }^{-1}$, etc.), 'Green Fodder' (ensilage) (i.e., harvested material, chopped, and not yet compacted), and 'Silage' (that had undergone the entire ensiling process).

For articles to be incorporated into the Types of Hybrids database, they needed to contain information on the morphological characteristics of corn plants and an evaluation of the chemical composition of green forage and whole plant silages produced under Brazilian experimental conditions. The final tabulated data were obtained from experiments published between January 1994 and December 2014. The data sub-bases Corn Cultivation and Green Fodder were composed of 49 experiments with 481 treatments and the data subbase Silage was composed of 24 experiments with 163 treatments; involving 478 silos.

The Types of Hybrids database was composed of data from the following publications: Alvarez, Pinho and Borges (2006); Alves, Ceccon and Leite (2013); Andrade, Dourado and Candido (2005); Assis et al. (2014); Beleze et al. (2003a, 2003b); Borghi, Crusciol, Costa and Mateus (2006); Cecato et al. (2007); Farinelli and Lemos (2010); Flaresso, Gross and Almeida (2000); Gimenes et al. (2006a, 2006b); Goes, Rodrigues, Takasu and Arf (2013); M. D. S. Gomes, Von Pinho, Oliveira, Ramalho and Viana (2002); Gralak et al. (2014); Jaremtchuk et al.
(2005); Lobato, Von Pinho, Von Pinho and Ramalho (2005); Lupatini, Maccari, Zanette, Piacentini and Neumann (2004); Mello, Nörnberg, Rocha and David (2005); Mendes, Von Pinho, Pereira, Farias and Souza (2008); F. C. L. Oliveira et al. (2011); J. S. E. Oliveira et al. (2003); Oliveira, Jobim, Silva and Bumbieris (2013); Paterniani, Ferreira, Duarte and Gallo (2010); Pedroso, Ezequiel, Osuna and Santos (2006); Pereira, Von Pinho, Souza, Santos and Fonseca (2011); Pimentel, Silva, Valadares, Cecon and Santos (1998); Pinho, Vasconcelos, Borges and Rezende (2006); Pinto et al. (2010); Ramos et al. (2002); Resende, Von Pinho and Vasconcelos (2003); Restle et al. (2002); Rodrigues, Andrade, Ruzante, Lima and Melotti (2002); Rodrigues et al. (2004); Rosa et al. (2004a, 2004b); Sangoi et al. (2006); Santos, Silva, Carvalho and Caione (2010); Senger, Mühlbach, Sánchez, Peres and Lima (2005); A. V. Silva et al. (2005, 2006); P. C. Silva et al., (2003); Souza and Soratto (2006); Storck, Cargnelutti, Lopes, Toebe and Silveira (2009); Tres et al. (2014); Velho et al. (2006, 2007); Vieira et al. (2013a, 2013b); Vilela et al. (2008); Von Pinho, Vasconcelos, Borges and Resende (2007); Zeoula et al. (2003a, 2003b); Zopollatto et al. (2009).

\section{Data sub-bases}

The Corn Cultivation data sub-base incorporated the variables: altitude $(\mathrm{m})$, rainfall $(\mathrm{mm})$, average annual temperature $\left({ }^{\circ} \mathrm{C}\right)$, spacing between rows $(\mathrm{m})$, number of plants ha ${ }^{-1}$, cutting age (days), number of ears per plant, plant height (m), shoot height (m), $\mathrm{DM}$ yield $\left(\mathrm{t} \mathrm{ha}^{-1}\right)$, grain yield $(\mathrm{kg})$, stem diameter $(\mathrm{mm})$, stem (\%), leaf (\%), DM of stalks, leaves, and spikes.

The Green Fodder data sub-base incorporated the variables: $\mathrm{DM}$, organic matter $(\mathrm{OM})$, neutral detergent fiber (NDF), acid detergent fiber (ADF), acid detergent lignin (ADL), crude protein (CP), ether extract (EE), and in vitro digestibility of DM (IVDDM). 
The Silage data sub-base incorporated the variables $\mathrm{DM}, \mathrm{OM}$, total carbohydrates (TCHO), non-fibrous carbohydrates (NFC), NDF, ADF, cellulose (CEL), hemicelluloses (HEM), ADL, $\mathrm{CP}$, ammoniacal nitrogen $\left(\mathrm{N}-\mathrm{NH}_{3} / \mathrm{CP}\right), \mathrm{pH}, \mathrm{EE}$, IVDDM, and total digestible nutrients.

\section{Statistical analyses}

The data of each sub-base were statistically analyzed using the MEANS and UNIVARIATE procedures and by analyses of variance using the MIXED procedure of the statistical software SAS (Statistical Analysis System Institute [SAS Institute], 2002). The restricted maximum likelihood approach (REML) was used whereby each observation was divided into two independent parts, i.e., related to the fixed effects and random effects, to eliminate the bias resulting from the loss of degrees of freedom in estimating the fixed effects of the model. This provides non-biased estimators with minimum variance for a balanced dataset. The REML method is the most highly recommended method to analyze unbalanced data, whereby each variable can present a different number of observations (Henderson, 1975; SAS Institute, 2002), as was the case in the meta-analysis database. For the analysis of variance, the number of repetitions was considered as the random effect; in the Corn Cultivation and Green Fodder sub-bases, the number of plots per treatment was considered a random effect; and in the Silage sub-base, the number of silos per treatment was considered a random effect. The type of hybrid (simple, double, or triple) was considered a fixed effect. No random effect was used for the variables: altitude, precipitation, and average annual temperature. The means were compared using a Tukey-Kramer test, considering the probability of $\mathrm{P}$ $<0.05$ to be statistically signifcant.

\section{Results and Discussion}

The mean altitude values (Table 1) of the different types of maize hybrids were consistent with those recommended for the species (i.e., above $500 \mathrm{~m}$ ). Altitude is usually linked to temperature variations that occur between day- and night-time, which facilitate the deposition of photoassimilates because metabolism is reduced during the cooler night-time. Rotili et al. (2014) evaluated the profitability of different maize hybrids and verified that it was influenced by the hybrid types used, by the environmental conditions, and by the interactions between the hybrid types and environmental factors. According to M. S. J. Silva et al. (2015), the criteria used by producers in the South of Brazil in selecting a type of hybrid were based on productivity (27.5\%), nutritional value $(22.5 \%)$, a combination of both characteristics $(12.5 \%)$, and other parameters $(37.5 \%)$. It is important to consider the location of the agricultural plot when selecting the type of hybrid to be used.

The differences $(\mathrm{P}=0.0095)$ observed in the spacing between rows were probably due to small variations in the crops, since at a distance of $<75$ $\mathrm{cm}$ between rows, a greater loss at harvest has been confirmed, i.e., during the power take-off. Martin, Venturini, Api, Pagnoncelli and Vieira (2011) conducted a study on the profile of Paraná properties and highlighted that the average row spacing used in maize sowing was similar in the years 2007 and 2008, i.e., $0.83 \mathrm{~m}$ and $0.81 \mathrm{~m}$, respectively. 


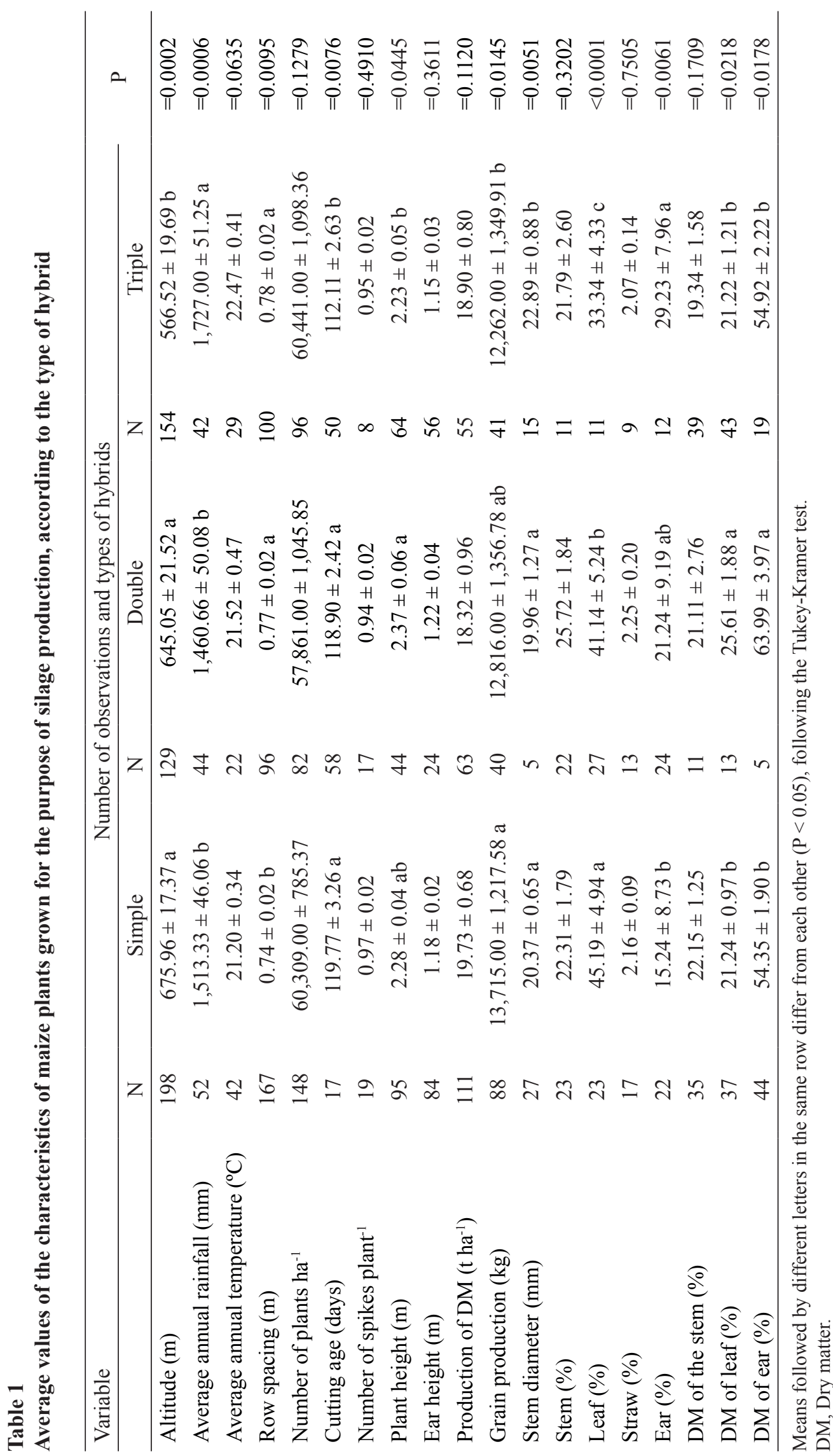


No differences $(\mathrm{P}=0.1279)$ were detected in terms of the number of corn plants per hectare at the time of harvest. This finding demonstrates that care is taken regarding the quantity of seeds used, especially because the size of stands (i.e., smaller stands) affect the DM yield per hectare and, therefore, this characteristic is of fundamental importance to reduce costs, increase productivity, and maximize returns from investments. According to Zardin et al. (2017), the choice of the cultivation area, silage process, as well as the management and utilization of corn silage can comprise at least 180 days (if the selection of the area for plant cultivation and its correction with liming and fertilizers are correctly considered) until it is ingested by animals in the production system. However, the time required for this entire process can vary because it depends on several factors, such as the initial soil fertility, meteorological conditions, hybrid cycle, fermentation time, and timing for silo opening and silage utilization.

There was no difference $(\mathrm{P}=0.4910)$ in the spike number per plant between hybrid types, however, it is noteworthy that this variable was only evaluated in a few studies. Ideally, there should be at least one spike per plant, but for all hybrids, the values were below 1 spike per plant, which demonstrates a limitation in production. These values corroborated the results of Araújo et al. (2016), in which the plant stand ranged from 61 to 65 thousand plants per ha and the number of spikes harvested varied from 57 to 67 thousand per hectare.

The height of the plants of the double hybrid type did not differ $(\mathrm{P}>0.05)$ from those of the simple type, and they in turn did not differ $(\mathrm{P}>0.05)$ from the triple hybrid type. However, there was a difference $(\mathrm{P}=0.0455)$ between the double and triple hybrid types. Very high plants are not relevant since there is generally a need to concentrate higher lignin content to provide support for them to remain standing during cultivation, which compromises the digestibility of nutrients, especially the ligninassociated NDF that is not degraded by ruminal bacteria (Hall, 2014; Huhtanen, Detmann, \& Krizsan, 2016; Van Soest, 1994). Despite the differences in plant height, there was no variation $(\mathrm{P}=0.3611)$ with relation to the height of the spikes. However, the measurement of the insertion height of the spikes is of fundamental importance to determine the cutting height so as to increase the energy quality of the silage as well as the amount of residual OM (Hülse et al., 2017). This is because an increase in the cutting height from 15 to $45 \mathrm{~cm}$ from the soil provides a higher starch content and a lower fiber content in corn silage, which increases the digestible DM harvest per hectare (Lynch, Baah, \& Beauchemin, 2015).

Although the production of DM per hectare is of fundamental importance in the calculation of the cost-benefit ratio in corn silage production, it is verified that not all experiments measured this parameter, i.e., only $56.0 \%, 48.8 \%$, and $35.7 \%$ of studies involving the simple, double, and triple hybrid types, respectively. Although the reported value of 18.98 tons of DM per hectare, i.e., general production average in the studies conducted in Brazil, is fair, it is necessary to continue to strive to increase productivity by reducing or further diluting the costs of production. According to Ferraretto et al. (2018), whole-plant corn silage stands out because of lower harvesting costs due to the high production of DM per hectare.

The yields of grains per hectare were equal between the simple and double hybrid types ( $\mathrm{P}>$ $0.05)$, and double and triple hybrid types $(\mathrm{P}>0.05)$, but there was a difference $(\mathrm{P}=0.0145)$ between the simple and triple hybrid types. The finding is presumed to be because simple hybrids are genetically developed to increase grain production while triple hybrid types generally present fairly leaf characteristics, however, this notion was not verified in the present meta-analysis, possibly because of the small number of evaluations on the composition of corn plants. The verified values of grain production per hectare showed that corn silage should be classified as bulky-concentrated or even 
concentrated-bulky feed, as a function of the highest percentage of grain. This feature makes corn silage a feed with unique nutritional properties due to its high levels of NFC in the form of starches and also provides physically effective digestible fiber. Tylutki et al. (2008) showed that the growth of bacteria that ferment NFCs and fibrous carbohydrates could be stimulated simultaneously, favoring the production of ruminal microbial protein.

The data presented in Table 2 indicated that the evaluation of green forage in silage (harvested material, chopped, and not yet compacted) was inadequate to compare the types of maize hybrids. In silage, the chemical composition of the forage mass can be altered by the activity of plant enzymes and microorganisms in the time between maize cutting and compaction in the silo. In this context, the consumption of soluble carbohydrates and other non-structural components increase the fiber content in neutral and acid detergents (NDF and $\mathrm{ADF})$. The differences $(\mathrm{P}=0.0274)$ in $\mathrm{CP}$ content between hybrid types probably stem from the low coefficients of intrinsic variation of this variable in maize plants.

The differences $(\mathrm{P}=0.0008)$ in IVDDM verified between the types of hybrids should be interpreted with caution because of the small number of evaluations and because of the differences among the methods of determination used. Velho et al. (2014) recommend that the comparison of digestibility of corn silages, when performed in vitro, should involve 24 hours of incubation, as longer times indicate indigestibility and generally mask possible differences between hybrids.
Table 3 shows that the parameter of the highest number of evaluations in corn silages is the DM content, which is the basic parameter needed to determine the chemical composition as well as the nutritional value of the silage. However, regarding the other parameters, it is evident that the evaluations of the chemical compositions are incomplete. These results can be partially explained by the lack of financial resources designated to research in Brazil. The importance of scientific progression and the determination of public policies were verified using a meta-analysis (Gurevitch et al., 2018).

The $\mathrm{OM}$ and total carbohydrates differed among hybrid types $(\mathrm{P}=0.0107$ and $\mathrm{P}=0.0162$, respectively), probably due to the low coefficients of variation that naturally occur within these variables. The values of both parameters were consistent with those reported in both the national literature (B. A. M. Gomes et al., 2015; Hentz et al., 2017) and international literature (Akins \& Shaver, 2014; Ferraretto \& Shaver, 2015).

Few studies (29 treatments) have assessed the NFC content, despite it being an essential factor because it can indirectly inform the amount of energy (starch) of corn silage, i.e., one of the main components that provides energy to the ruminal microorganisms as well as to the host (Van Soest, 1994). It should be noted that despite the importance of starch in the constitution of corn silages, information regarding this carbohydrate is not shown in Table 3 because most of the articles within the study period did not include this information. According to the Fundação ABC (2018), the average starch content of corn silage under the conditions of rural producers is $32 \%$ in DM. 
Table 2

Average values of chemical compositions of maize ensilages, according to the type of hybrid

\begin{tabular}{|c|c|c|c|c|c|c|c|}
\hline \multirow{2}{*}{ Variable } & \multicolumn{6}{|c|}{ Number of observations and type of hybrid } & \multirow{2}{*}{$P$} \\
\hline & $\mathrm{N}$ & Simple & $\mathrm{N}$ & Double & $\mathrm{N}$ & Triple & \\
\hline Dry matter ${ }^{1}$ & 64 & $31.02 \pm 1.15$ & 33 & $29.16 \pm 1.70$ & 70 & $28.69 \pm 1.47$ & $=0.1249$ \\
\hline Organic matter ${ }^{2}$ & 8 & $87.5 \pm 2.10$ & 4 & $87.25 \pm 2.14$ & 10 & $87.78 \pm 2.51$ & $=0.6730$ \\
\hline Neutral detergent fiber ${ }^{2}$ & 35 & $46.89 \pm 1.42$ & 13 & $48.11 \pm 2.25$ & 38 & $48.74 \pm 1.98$ & $=0.5094$ \\
\hline Acid detergent fiber ${ }^{2}$ & 33 & $26.56 \pm 1.04$ & 12 & $29.11 \pm 1.67$ & 36 & $26.57 \pm 1.47$ & $=0.2011$ \\
\hline Lignin $^{2}$ & 14 & $7.02 \pm 0.58$ & 10 & $7.17 \pm 0.69$ & 17 & $8.73 \pm 0.53$ & $=0.0725$ \\
\hline Crude protein ${ }^{2}$ & 33 & $7.16 \pm 0.20 \mathrm{~b}$ & 21 & $7.83 \pm 0.29 \mathrm{a}$ & 38 & $7.32 \pm 0.28 b$ & $=0.0274$ \\
\hline Ether extract ${ }^{2}$ & 12 & $2.05 \pm 0.20$ & 8 & $1.85 \pm 0.21$ & 20 & $2.03 \pm 0.25$ & $=0.4683$ \\
\hline IVDDM $^{2}$ & 12 & $73.05 \pm 2.85 \mathrm{a}$ & 8 & $72.74 \pm 3.49 \mathrm{a}$ & 18 & $59.38 \pm 2.33 b$ & $=0.0008$ \\
\hline
\end{tabular}

${ }^{1}$, Percentage in natura matter; ${ }^{2}$, Percentage dry matter; IVDDM, In vitro digestibility of dry matter. Means followed by different letters in the same row differ from each other $(\mathrm{P}<0.05)$, following the Tukey-Kramer test.

Table 3

Average values of the chemical compositions of silages from different types of maize hybrids

\begin{tabular}{|c|c|c|c|c|c|c|c|}
\hline \multirow[t]{2}{*}{ Variable } & \multicolumn{6}{|c|}{ Number of observations and type of hybrid } & \multirow[t]{2}{*}{$\mathrm{P}$} \\
\hline & $\mathrm{N}$ & Simple & $\mathrm{N}$ & Double & $\mathrm{N}$ & Triple & \\
\hline Dry matter ${ }^{1}$ & 54 & $30.93 \pm 0.73$ & 48 & $31.21 \pm 0.77$ & 49 & $31.13 \pm 0.76$ & $=0.9622$ \\
\hline Organic matter ${ }^{2}$ & 28 & $94.77 \pm 0.75 \mathrm{a}$ & 11 & $95.94 \pm 0.94 \mathrm{ab}$ & 30 & $96.97 \pm 0.77 \mathrm{~b}$ & $=0.0107$ \\
\hline Total carbohydrates ${ }^{2}$ & 19 & $85.50 \pm 0.45 \mathrm{a}$ & 8 & $84.28 \pm 0.62 \mathrm{ab}$ & 27 & $84.11 \pm 0.48 b$ & $=0.0162$ \\
\hline Non-fibrous carbohydrates ${ }^{2}$ & 3 & $20.46 \pm 2.78$ & 7 & $23.99 \pm 3.65$ & 19 & $23.92 \pm 3.46$ & $=0.7985$ \\
\hline Neutral detergent fiber ${ }^{2}$ & 36 & $54.52 \pm 1.15$ & 38 & $55.17 \pm 1.21$ & 46 & $55.53 \pm 1.02$ & $=0.8041$ \\
\hline Acid detergent fiber ${ }^{2}$ & 36 & $27.10 \pm 0.96$ & 26 & $28.05 \pm 1.27$ & 44 & $29.54 \pm 0.97$ & $=0.0511$ \\
\hline Hemicelulose $^{2}$ & 36 & $28.29 \pm 0.88$ & 26 & $27.05 \pm 1.18$ & 44 & $27.24 \pm 0.91$ & $=0.4024$ \\
\hline Cellulose $^{2}$ & 3 & $26.72 \pm 0.92 \mathrm{a}$ & 8 & $23.56 \pm 0.56 b$ & 8 & $26.05 \pm 0.56 \mathrm{a}$ & $=0.0081$ \\
\hline Lignin $^{2}$ & 5 & $4.29 \pm 1.14$ & 20 & $4.98 \pm 0.57$ & 22 & $5.81 \pm 0.55$ & $=0.5811$ \\
\hline IVDDM & 3 & $57.18 \pm 3.41 \mathrm{~b}$ & 23 & $64.83 \pm 2.19 \mathrm{a}$ & 13 & $48.46 \pm 2.58 \mathrm{c}$ & $<0.0001$ \\
\hline Total digestible nutrients (\%) & 38 & $69.25 \pm 0.83$ & 7 & $68.43 \pm 1.54$ & 22 & $68.49 \pm 0.89$ & $=0.6209$ \\
\hline $\mathrm{pH}$ & 13 & $3.56 \pm 0.11 \mathrm{c}$ & 13 & $3.72 \pm 0.09 \mathrm{~b}$ & 18 & $3.96 \pm 0.12 \mathrm{a}$ & $<0.0001$ \\
\hline Ether extract ${ }^{2}$ & 20 & $2.77 \pm 0.21$ & 14 & $2.33 \pm 0.25$ & 31 & $2.86 \pm 0.22$ & $=0.0872$ \\
\hline Crude protein ${ }^{2}$ & 41 & $7.71 \pm 0.18$ & 31 & $7.68 \pm 0.21$ & 46 & $8.06 \pm 0.17$ & $=0.2547$ \\
\hline Ammoniacal nitrogen ${ }^{3}$ & 8 & $2.24 \pm 1.88$ & 6 & $0.15 \pm 1.80$ & 18 & $1.74 \pm 2.08$ & $=0.2413$ \\
\hline
\end{tabular}

${ }^{1}$, Percentage in natura matter; ${ }^{2}$, Percentage dry matter; ${ }^{3}$, Percentage total nitrogen; IVDDM, In vitro digestibility of dry matter. Means followed by different letters in the same row differ from each other $(\mathrm{P}<0.05)$, following the Tukey-Kramer test. 
The contents of NDF, ADF, HEM, and lignin also did not differ $(\mathrm{P}>0.05)$. However, the NDF levels were considered to be high, especially when compared to the values reported in international literature (Akins \& Shaver, 2014; Ferraretto \& Shaver, 2015) and also when compared to the average values over 10 years of the Concurso de Silagem de Milho da Fundação ABC (Fundação $\mathrm{ABC}, 2018)$, i.e., $43.0 \%$ of NDF in DM. These values deserve special focus because they are derived from Brazilian research, and mainly because the NDF content is the main limitation of voluntary intake (Van Soest, 1994). Therefore, the digestibility of NDF in the total gastrointestinal tract was higher for the hybrid with a brown central vein, which resulted in higher milk yields (Lim, Nestor, \& Kung, 2015), and the use of corn silage with a higher digestibility increased the voluntary intake of silage, increased milk production, and reduced methane emissions (Hassanat, Gervais, \& Benchaar, 2017).

From the results of the present study, it is evident that for effective comparisons of the types of hybrids to be made, it is necessary that crop data (number of plants per hectare, height of plants, height of spike insertion, etc.) are evaluated completely. In Brazil, there are issues associated with the silage process and the consumption of soluble sugars alters the carbohydrate partition between the plants and the silage produced. This affects the composition of the silage and, therefore, it is essential to refer to the basic assumptions of silage production (Figure 1), regardless of the type of hybrid used, because the quality of the final product depends on all the steps involved in this process.

The purpose of the present study was to integrate all available, relevant information published in the public domain, to enable an overall view of the chemical composition of corn plants, green forage, and silages from the simple, double, and triple maize hybrids used in Brazil. The present study thus provides a foundation from which critical analyses can be conducted on corn silage as fodder, under Brazilian conditions. Furthermore, we demonstrated the need for chemical compositions to be analyzed in a complete way in future studies. 


\section{Land and infrastructure for maize silage production}

Climatic conditions (Uncontrollable). Scale the size of the silo. Determine size of silage slice removed to avoid aerobic instability. Determination of soil, soil analysis, correction with liming and fertilizers. Hybrid decision, row spacing, number of seeds per hectare, controlling weeds, pests, and diseases.

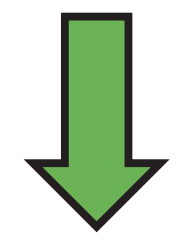

\section{Ensilage procedure for maize plants}

Determination of the cut-off point. Wiring of the fork blades. Size of the particle. Use of inoculant. Compressing the ensiled material. Time for silo closing. Silo fence.

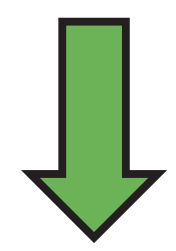

\section{Corn silages}

Handling of canvas. Form of silage removal from silos. Take care not to chop too much on the forage wagon. Formulate the diet based on the nutritional requirements of the animals.

Figure 1. Basic assumptions for the production of whole plant maize silage.

\section{Conclusions}

The types of maize hybrids (simple, double, or triple) differed mainly in terms of grain production.
In many situations, the silage processes are not conducted in an ideal way, and the differences due to maize plants (i.e., type of hybrid) are minimized due to losses during the ensiling process. 


\section{Acknowledgments}

We thank the Financiadora de Estudos e Projetos (FINEP) of the Ministério da Ciência e Tecnologia (MCT) for the financial resources made available in the Public Call MCT/FINEP/CT-INFRA CAMPI REGIONAIS - 01/2010 which allowed the Universidade Federal de Santa Maria - Campus of Palmeira das Missões to establish the Laboratório de Estudos sobre a Interface Planta-Animal, containing the Laboratório de Estudos de Metanálise, under the coordination of Prof. João Pedro Velho. This study was financed in part by the Coordenação de Aperfeiçoamento de Pessoal de Nível Superior Brasil (CAPES; Finance Code 001). We also thank the Fundo de Incentivo à Pesquisa da Universidade Federal de Santa Maria (FIPE - UFSM) for the grant awarded to Cássio Rodrigo Gehrke.

\section{References}

Akins, M. S., \& Shaver, R. D. (2014). Influence of corn silage hybrid type on lactation performance by Holstein dairy cows. Journal of Dairy Science, 97(12), 7811-7820. doi: 10.3168/jds.2014-8400

Alvarez, C. G. D., Pinho, R. V., \& Borges, I. D. (2006). Avaliação de características bromatológicas da forragem de milho em diferentes densidades de semeadura e espaçamentos entre linhas. Ciência e Agrotecnologia, 30(6), 409-414. doi: 10.1590/ S1413-70542006000300004

Alves, V. B., Ceccon, G., \& Leite, L. F. (2013) Morfologia e produtividade de híbridos de milho Safrinha solteiro e consorciado com braquiária. Revista Brasileira de Milho e Sorgo, 12(2), 152-163. doi: 10.18512/19806477/rbms.v12n2p152-163

Andrade, J. A. D. C., Dourado, M. C., \& Candido, L. S. (2005) Estabilidade e caracterização fenotípica de híbridos experimentais e comerciais de milho em quatro épocas de plantio. Revista Brasileira de Milho e Sorgo, 4(3), 390-403. doi: 10.18512/1980-6477/ rbms.v4n3p390-403

Araújo, L. D., Silva, L. G. B., Silveira, P. M., Rodrigues, F., Lima, M. L.P., \& Cunha, P. C. R. (2016). Desempenho agronômico de híbridos de milho na região sudeste de Goiás. RevistaAgro@mbiente Online, 10(4), 334-341. doi: 10.18227/1982-8470ragro. v10i4.3334
Assis, F. B., Basso, F. C., Lara, E. C., Raposo, E., Bertipaglia, L. M. A., Fernandes, L. O., . . \& \& Reis, R. A. (2014). Caracterização agronômica e bromatológica de híbridos de milho para ensilagem. Semina: Ciências Agrárias, 35(6), 2869-2882. doi: 10.5433/1679-0359.2014v35n6p2869

Beleze, J. R. F., Zeoula, L. M., Cecato, U., Dian, P. H. M., Martins, E. M., \& Falcão, A. D. S. (2003a). Avaliação de cinco híbridos de milho (Zea mays, L.) em diferentes estádios de maturação. 1. Produtividade, características morfológicas e correlações. Revista Brasileira de Zootecnia, 32(3), 529-537. doi: 10.1590/S1516-35982003000300004

Beleze, J. R. F., Zeoula, L. M., Cecato, U., Dian, P. H. M., Martins, E. M., \& Falcão, A. D. S. (2003b). Avaliação de cinco híbridos de milho (Zea mays, L.) em diferentes estádios de maturação. 2. Concentrações dos componentes estruturais e correlações. Revista Brasileira de Zootecnia, 32(3), 538-545. doi: 10.1590/S1516-35982003000300005

Bernardes, T. F. \& Rêgo, A. C. (2014). Study on the practices of silage production and utilization on Brazilian dairy farms. Journal of Dairy Science, 97(3), 1852-1861. doi: 10.3168/jds.2013-7181

Borghi, É., Crusciol, C. A. C., Costa, C., \& Mateus, G. P. (2006). Produtividade e qualidade das forragens de milho e de Brachiaria brizantha em sistema de cultivo consorciado. Revista Brasileira de Milho e Sorgo, 5(3), 369-381. doi: 10.1590/S180692902015000900001

Capper, J. L. (2011). The environmental impact of beef production in the United States: 1977 compared with 2007. Journal of Animal Science, 89(12), 4249-4261. doi: $10.2527 /$ jas.2010-3784

Capper, J. L., Cady, R. A., \& Bauman, D. E. (2009). The environmental impact of dairy production: 1944 compared with 2007. Journal of Animal Science, 87(6), 2160-2167. doi: 10.2527/jas.2009-1781.

Cecato, U., Moreira, A. L., Damasceno, J. C., Santos, G. T., Rodrigues, A. M., \& Barbosa, M. A. A. F. (2007). Caracterização agronômica e composição química de híbridos de milho. Acta Scientiarum. Animal Sciences, 29(2), 121-127. doi: 10.5433/1679-0359.2014v35n $6 \mathrm{p} 2869$

Costa, E. F. N., Souza, J. C., Lima, J. L., \& Cardoso, G. A. (2010). Interação entre genótipos e ambientes em diferentes tipos de híbridos de milho. Pesquisa Agropecuária Brasileira, 45(12), 1433-1440. doi: 10.1590/S0100-204X2010001200014 
Driehuis, F., Wilkinson, J. M., Jiang, Y., Ogunade, I., \& Adesogan, A. T. (2018). Silage review: animal and human health risks from silage. Journal of Dairy Science, 101(5), 4093-4110. doi: 10.3168/jds.201713836

Emygdio, B. M., Ignaczak, J. C., \& Cargnelutti, A. F. (2007). Potencial de rendimento de grãos de híbridos comerciais simples, triplos e duplos de milho. Revista Brasileira de Milho e Sorgo, 6(1), 95-103. doi: 10.18512/1980-6477/rbms.v6n1p95-103

Farinelli, R., \& Lemos, L. B. (2010). Produtividade e eficiência agronômica do milho em função da adubação nitrogenada e manejos de solo. Revista Brasileira de Milho e Sorgo, 9(2), 135-146. doi: 10.18512/1980-6477/rbms.v9n2p135-146

Ferraretto, F. L., \& Shaver, D. R. (2015). Effects of wholeplant corn silage hybrid type on intake, digestion, ruminal fermentation, and lactation performance by dairy cows through a meta-analysis. Journal of Dairy Science, 98(4), 2662-2675. doi: 10.3168/ jds.2014-9045

Ferraretto, L. F., Shaver, R. D., \& Luck, B. D. (2018). Silage review: Recent advances and future technologies for whole-plant and fractionated corn silage harvesting. Journal of Dairy Science, 101(5), 3937-3951. doi: 10.3168/jds.2017-13728

Flaresso, J. A., Gross, C. D., \& Almeida, E. X. (2000). Cultivares de milho (Zea mays L. e Sorgo (Sorghum bicolor (L.). Moench.). para ensilagem no alto Vale do Itajaí, Santa Catarina. Revista Brasileira de Zootecnia, 29(6), 1608-1615. doi: 10.1590/S151635982000000600003

Fundação ABC. (2018). Concurso de silagem de milho da Fundação ABC: 10 anos de conquistas. Castro: Fundação ABC. Recuperado de http://www. fundacaoabc.org.br

Gimenes, A. L. G., Mizubuti, I. Y., Moreira, F. B., Pereira, E. S., Ribeiro, E. L. A., \& Mori, R. M. (2006a). Composição química e estabilidade aeróbia em silagens de milho preparadas com inoculantes bacteriano e/ou enzimático. Acta Scientiarum. Animal Sciences, 28(2), 153-158. doi: 10.4025/ actascianimsci.v28i2.640

Gimenes, A. L. G., Mizubuti, I. Y., Moreira, F. B., Pereira, E. S., Ribeiro, E. L. A., \& Mori, R. M. (2006b). Degradabilidade in situ de silagens de milho confeccionadas com inoculantes bacteriano e/ ou enzimático. Acta Scientiarum. Animal Sciences, 28(1), 11-16. doi: 10.4025/actascianimsci.v28i1.658
Goes, R. J., Rodrigues, R. A. F., Takasu, A. T., \& Arf, O. (2013). Características agronômicas e produtividade do milho sob fontes e doses de nitrogênio em cobertura no inverno. Revista Brasileira de Milho e Sorgo, 12(3), 250-259. doi: 10.18512/1980-6477/ rbms.v12n3p250-259

Gomes, B. A. M., Moraes, V. G., Jobim, C. C., Santos, C. T., Oliveira, M. T., \& Rossi, M. R. (2015). Composição nutricional e degradabilidade ruminal da silagem de milho (Zea mays L.). com adição de glicerina na ensilagem. Semina. Ciências Agrárias, 36(3), 20702092. doi: 10.5433/1679-0359.2015v36n3Supl1p2079

Gomes, M. D. S., Von Pinho, R. G., Oliveira, J. S. E., Ramalho, M. A. P., \& Viana, A. C. (2002). Adaptabilidade e estabilidade de cultivares de milho para produtividade de matéria seca e degradabilidade ruminal da silagem. Revista Brasileira de Milho e Sorgo, 1(2), 83-90. doi: 10.18512/1980-6477/rbms. v1n 2 p $83-90$

Gralak, E., Faria, M. V., Possato, O., Jr., Rossi, E. S., Augusto, C., Silva, D. A., . . Neumann, M. (2014). Capacidade combinatória de híbridos de milho para caracteres agronomicos e bromatológicos da silagem. Revista Brasileira de Milho e Sorgo, 13(2), 187-200. doi: 10.18512/1980-6477/rbms.v13n2p187-200

Gurevitch, J., Koricheva, J., Nakagawa, S., \& Stewart, G. (2018). Meta-analysis and the science of research synthesis. Nature, 555(7695), 175-182. doi: 10.1038/ nature 25753

Hall, M. B. (2014). Feed analyses and their interpretation. Veterinary Clinics of North America - Food Animal Practice, 30(3), 487-505. doi: 10.1016/j. cvfa.2014.07.001

Hassanat, F., Gervais, R., \& Benchaar, C. (2017). Methane production, ruminal fermentation characteristics, nutrient digestibility, nitrogen excretion, and milk production of dairy cows fed conventional or brown midrib corn silage. Journal of Dairy Science, 100(4), 2626-2636. doi: 10.3168/jds.2016-11862

Henderson, C. H. (1975). Best linear estimation and prediction under a selection model. Biometrics, Washington D.C., 31(2), 423-447. doi: $10.2307 / 2529430$

Hentz, F., Velho, J. P., Nörnberg, J. L., Haygert-Velho, I. M. P., Henz, E. L., Henn, J. D.,... Zardin, P. B. (2017). Fractionation of carbohydrates and nitrogenous constituents of latecrop corn silages ensiled with different specific masses. Semina. Ciências Agrárias, 38(1), 491-502. doi: 10.5433/1679-0359.2017v38n1p491 
Hollmann, M., Allen, M. S., \& Beede. D. K. (2011). Diet fermentability influences lactational performance responses to corn distillers grains: A meta-analysis. Journal of Dairy Science, 94(4), 2007-2021. doi: $10.3168 /$ jds.2010-3711

Huhtanen, P., Detmann, E., \& Krizsan, S. J. (2016). Prediction of rumen fiber pool in cattle from dietary, fecal, and animal variables. Journal of Dairy Science, 99(7), 5345-5357. doi: $10.3168 /$ jds.2015-10842

Hülse, J., Neumann, M., Ueno, R. K., Heker Jr., J. C., Figueira, D. N., Sandini, I. E.,... Vigne, G. L. D. (2017). Nutrient balance in the soil and nutritive characteristics of maize silage cut at different heights. Semina: Ciências Agrárias, 38(6), 3779-3796. doi: 10.5433/1679-0359.2017v38n6p3779

Jaremtchuk, A. R., Jaremtchuk, C. C., Baglioli, B., Medrado, M. T., Kozlowski, L. A., Costa, C., \& Madeira,H.M. F. (2005). Características agronômicas e bromatológicas de vinte genótipos de milho (Zea mays L.). para silagem na região leste paranaense. Acta Scientiarum. Animal Sciences, 27(2), 181-188. doi: $10.4025 /$ actascianimsci.v27i2.1220

Kleinschmit, D. H., \& Kung, L., Jr. (2006). A metaanalysis of the effects of Lactobacillus buchneri on the fermentation and aerobic stability of corn and grass and small-grain silages. Journal of Dairy Science, 89(10), 4005-4014. doi: 10.3168/jds.S00220302(06) 72444-4

Krüger, A. M., Jobim, C. C., Carvalho, I. Q., \& Moro, J. G. (2017). A simple method for determining maize silage density on farms. Tropical GrasslandsForrajes Tropicales, 5(2), 94-99. doi: 10.17138/ $\operatorname{tgft}(5) 94-99$

Lim, J. M., Nestor, K. E., Jr., \& Kung, L., Jr. (2015). The effect of hybrid type and dietary proportions of corn silage on the lactation performance of highproducing dairy cows. Journal of Dairy Science, 98(2), 1195-1203. doi: 10.3168/jds.2014-8725

Lobato, P. N., Von Pinho, R. G., Von Pinho, É. V. R., \& Ramalho, M. A. P. (2005). Qualidade fisiológica e sanitária de sementes de híbridos duplos de milho utilizando a geração F1 e F2 de híbridos. Revista Brasileira de Milho e Sorgo, 4(1), 54-64. doi: 10.18512/1980-6477/rbms.v4n1p54-64

Lovatto, P. A., Lehnen, C. R., Andretta, I., Carvalho, A. D., \& Hauschild, L. (2007). Meta-análise em pesquisas científicas - Enfoque em metodologias. Revista Brasileira de Zootecnia, 36, 285-301, suplemento especial. doi: 10.1590/S1516-35982007001000026
Lupatini, G. C., Maccari, M., Zanette, S., Piacentini, E., \& Neumann, M. (2004). Avaliação do desempenho agronômico de híbridos de milho (Zea mays, L.). para produção de silagem. Revista Brasileira de Milho e Sorgo, 3(2), 193-203. doi: 10.18512/19806477/rbms.v3n2p193-203

Lynch, J. P., Baah, J., \& Beauchemin, K. A. (2015). Conservation, fiber digestibility, and nutritive value of corn harvested at 2 cutting heights and ensiled with fibrolytic enzymes, either alone or with a ferulic acid esterase-producing inoculant. Journal of Dairy Science, 98(2), 1214-1224. doi: 10.3168/jds.20148768

Martin, T. N., Venturini, T., Api, I., Pagnoncelli, A., \& Vieira, P. A., Jr. (2011). Perfil do manejo da cultura de milho no sudoeste do Paraná. Revista Ceres, 58(1), 1-8. doi: 10.1590/S0034-737X2011000100001

Mello, R., Nörnberg, J. L., Rocha, M. G., \& David, D. B. (2005). Características produtivas e qualitativas de híbridos de milho para produção de silagem. Revista Brasileira de Milho e Sorgo, 4(1), 79-94. doi: 10.18512/1980-6477/rbms.v4n1p79-94

Mendes, M. C., Von Pinho, R. G., Pereira, M. N., Farias, E. M., Fo , \& Souza, A. X., Fo. (2008). Avaliação de híbridos de milho obtidos do cruzamento entre linhagens com diferentes níveis de degradabilidade da matéria seca. Bragantia, 67(2), 285-297. doi: 10.1590/S0006-87052008000200004

Nasrollahi, S. M., Imani, M., \& Zebeli, Q. (2015). A meta-analysis and meta-regression of the effect of forage particle size, level, source, and preservation method on feed intake, nutrient digestibility, and performance in dairy cows. Journal of Dairy Science, 98(12), 8926-8939. doi: 10.3168/jds.2015-9681

National Research Council. (2001). Nutrient Requirements of Dairy Cattle (7th ed.). Washington: National Academies Press.

National Research Council. (2016). Nutrient Requirements of Beef Cattle (7th ed.). Washington: National Academies Press.

Oliveira, F. C. L., Jobim, C. C., Silva, M. S., \& Bumbieris, V. H., Jr. (2013). Productive characteristics of maize hybrids at different cutting heights for silage and organic matter and mineral rates in post-harvest residues. Acta Scientiarum. Animal Sciences, 35(2), 133-138. doi: 10.4025/actascianimsci.v35i2.16642

Oliveira, F. C. L., Jobim, C. C., Silva, M. S., Calixto, M., Jr., Bumbieris, V. H., Jr., \& Roman, J. (2011). Produtividade e valor nutricional da silagem de 
híbridos de milho em diferentes alturas de colheita. Revista Brasileira de Zootecnia, 40(4), 720-727. doi: 10.1590/S1516-35982011000400004.

Oliveira, J. S. E., Souza, F. D., Sob ${ }^{\circ}$, Pereira, R. C., Miranda, J. M., Banys, V. L., Ruggieri, A. C.,... Auad, M. V. (2003). Potencial de utilização de híbridos comerciais de milho para silagem, na região sudeste do Brasil. Revista Brasileira de Milho e Sorgo, 2(1), 62-71. doi: 10.18512/1980-6477/rbms.v2n1p62-71

Oliveira, M. R., Bueno, A. V. I., Leão, G. F. M., Neumann, M., \& Jobim, C. C. (2018). Nutritional composition and aerobic stability of wheat and corn silages stored under different environmental conditions. Semina. Ciências Agrárias, 39(1), 253-260. doi: 10.5433/1679-0359.2018v39n1p253

Paterniani, M. E. A. G. Z., Ferreira, E. A., Duarte, A. P., \& Gallo, P. B. (2010). Potencial de híbridos top crosses de milho no estado de São Paulo. Revista Brasileira de Milho e Sorgo, 9(2), 163-176. doi: 10.18512/1980-6477/rbms.v9n2p163-176

Pedroso, S., Ezequiel, J. M. B., Osuna, J. T. A., \& Santos, V. C. (2006). Características agronômicas e nutricionais de híbridos de milho e suas silagens (Zea mays L.). ARS Veterinária, 22(3), 248-258. doi: 10.15361/2175-0106.2006v22n3p248-258

Pereira, J. L. A. R., Von Pinho, R. G., Souza, A. X. Fo., Santos, Á. O., \& Fonseca, R. G. (2011). Avaliação de componentes estruturais da planta de híbridos de milho colhidos em diferentes estádios de maturação. Revista Brasileira de Milho e Sorgo, 10(1), 47-55. doi: 10.18512/1980-6477/rbms.v10n1p47-55

Phuong, H. N., Friggens, N. C., Boer, J. M., \& Schmidely, P. (2013). Factors affecting energy and nitrogen efficiency of dairy cows: A meta-analysis. Journal of Dairy Science, 96(11), 7245-7259. doi: 10.3168/ jds.2013-6977

Pimentel, J. J. O., Silva, J. F. C., Valadares, S. C., Fo., Cecon, P. R., \& Santos, O. S. (1998). Effect of protein supplementation on the nutritive value of corn and sorghum silages. Revista Brasileira de Zootecnia, 27(5), 1042-1049.

Pinho, R. G. V., Vasconcelos, R. C., Borges, I. D., \& Rezende, A. V. (2006). Influence of cutting height of plants in agronomic characteristics and nutritive value of silages of corn and different types of sorghum. Revista Brasileira de Milho e Sorgo, 5(2), 266-279. doi: 10.18512/1980-6477/rbms.v5n2p266-279

Pinto, A. P., Lançanova, J. A. C., Lugão, S. M. B., Roque, A. P., Abrahã, J. J. S., Silva, J. O., Leme, M. C. J., \& Mizubuti, I. Y. (2010). Avaliação de doze cultivares de milho (Zea mays L.). para silagem. Semina. Ciências Agrárias, 31(4), 1071-1078. doi: 10.5433/1679-0359.2010v31n4p1071

Ramos, B. M. O., Pinto, A. P., Katsuki, P. A., Gomes, G. P., Podleskis, M. R., Folkowskis, T.,... Mizubuti, I. Y. (2002). Composição química de silagens de milho cultivado em dois tipos de solos da região norte do Paraná. Semina. Ciências Agrárias, 23(2), 239-248. doi: 10.5433/1679-0359.2002v23n2p239

Resende, S. G., Von Pinho, R. G., \& Vasconcelos, R. C. (2003). Influência do espaçamento entre linhas e da densidade de plantio no desempenho de cultivares de milho. Revista Brasileira de Milho e Sorgo, 2(2), 3442. doi: 10.18512/1980-6477/rbms.v2n3p34-42

Restle, J., Neumann, M., Brondani, I. L., Pascoal, L. L., Silva, J. H. S., Pellegrini, L. G., \& Souza, A. N. M. (2002). Manipulação da altura de corte da planta de milho (Zea mays, L.). para ensilagem, visando a produção do novilho superprecoce. Revista Brasileira de Zootecnia, 31(3), 1235-1244. doi: 10.1590/S1516-35982002000500021

Robinson, P. H., Swanepoel, W., Heguy, J. M., Price, T., \& Meyer, D. M. (2016). "Shrink" losses in commercially sized corn silage piles: Quantifying total losses and where they occur. Science of the Total Environment, 542(4), 530-539. doi: 10.1016/j. scitotenv.2015.10.090

Rodrigues, P. H. M., Andrade, S. J. T., Ruzante, J. M., Lima, F. R., \& Melotti, L. (2002). Valor nutritivo da silagem de milho sob o efeito da inoculação de bactérias ácido-láticas. Revista Brasileira de Zootecnia, 31(6), 2380-2385. doi: 10.1590/S151635982002000900029

Rodrigues, P. H. M., Ruzante, J. M., Senatore, A. L., Lima, F. R., Melotti, L., \& Meyer, P. M. (2004). Avaliação do uso de inoculantes microbianos sobre a qualidade fermentativa e nutricional da silagem de milho. Revista Brasileira de Zootecnia, 33(3), 538545. doi: $10.1590 /$ S1516-35982004000300003

Rosa, J. R. P., Restle, J., Silva, J. D., Pascoal, L. L., Pacheco, P. S., Faturi, C., \& Santos, A. D. (2004a). Avaliação da silagem de diferentes híbridos de milho (Zea mays, L.). por meio do desempenho de bezerros confinados em fase de crescimento. Revista Brasileira de Zootecnia, 33(4), 1016-1028. doi: 10.1590/S1516-35982004000400022

Rosa, J. R. P., Silva, J. H. S., Restle, J., Pascoal, L. L., Brondani, I. L., Alves, D. C., F ${ }^{\circ}$., \& Freitas, A. K. (2004b). Avaliação do comportamento agronômico da planta e valor nutritivo da silagem de diferentes 
híbridos de milho (Zea mays, L .). Revista Brasileira de Zootecnia, 33(2), 302-312. doi: 10.1590/S151635982004000200005

Rotili, E. A., Afférri, F. S., Peluzio, J. M., Carvalho, E. V., \& Santos, W. F. (2014). Rentabilidade de diferentes híbridos de milho, no Estado do Tocantins, safra 2009/2010. Journal of Biotechnology and Biodiversity, 5(2), 162-167. doi: 10.20873/jbb.uft. cemaf.v5n2.rotili

Sangoi, L., Silva, P. R. F., Silva, A. A., Ernani, P. R., Horn, D., Strieder, M. L.,... Schweitzer, C. (2006). Desempenho agronômico de cultivares de milho em quatro sistemas de manejo. Revista Brasileira de Milho e Sorgo, 5(2), 218-231. doi: 10.18512/19806477/rbms.v5n2p218-231

Santos, P. A., Silva, A. F., Carvalho, M. A. C., \& Caione, G. (2010). Adubos verdes e adubação nitrogenada em cobertura no cultivo do milho. Revista Brasileira de Milho e Sorgo, 9(2), 123-134. doi: 10.18512/19806477/rbms.v9n2p123-134

Sauvant, D., Schmidely, P., Daudin, J. J., \& Stpierre, N. R. (2008). Meta-analyses of experimental data in animal nutrition. Animal, 2(8), 1203-1214. doi: $10.1017 / \mathrm{S} 1751731108002280$

Senger, C. C. D., Mühlbach, P. R. F., Sánchez, L. M. B., Peres, D., Netto \& Lima, L. D. (2005). Composição química e digestibilidade "in vitro" de silagens de milho com distintos teores de umidade e níveis de compactação. Ciência Rural, 35(6), 1393-1399. doi: $10.1590 / \mathrm{S} 0103-84782005000600026$

Silva, A. V., Pereira, O. G., Garcia, R., Valadares, S. C., Fo, Cecon, P. R., \& Ferreira, C. L. L. F. (2005). Composição bromatológica e digestibilidade in vitro da matéria seca de silagens de milho e sorgo tratadas com inoculantes microbianos. Revista Brasileira de Zootecnia, 34(6), 1881-1890. doi: 10.1590/S151635982005000600011

Silva, A. V., Pereira, O. G., Valadares, S. C., Fo , Garcia, R., Cecon, P. R., \& Ferreira, C. L. L. F. (2006). Consumo e digestibilidades dos nutrientes em bovinos recebendo dietas contendo silagens de milho e sorgo, com e sem inoculante microbiano. Revista Brasileira de Zootecnia, 35(6), 2469-2478. doi: 10.1590/S1516-35982006000800037

Silva, M. S. J., Jobim, C. C., Poppi, E. C., Tres, T. T., \& Osmari, M. P. (2015). Production technology and quality of corn silage for feeding dairy cattle in Southern Brazil. Revista Brasileira de Zootecnia, 44(9), 303-313. doi: 10.1590/S180692902015000900001
Silva, P. C., Ayala-Osuna, J. T., Moro, J. R., Paiva, M. L., Queiroz, S. R. O. D., \& Martins R. M. (2003). Avaliação de híbridos interpopulacionais de milho quanto a características químicas e agronômicas para silagem. Revista Brasileira de Milho e Sorgo, 2(3), 111-120. doi: 10.18512/1980-6477/rbms. v2n $03 \mathrm{p} \% 25 \mathrm{p}$

Souza, E. D. F. C., \& Soratto, R. P. (2006). Efeito de fontes e doses de nitrogênio em cobertura, no milho safrinha, em plantio direto. Revista Brasileira de Milho e Sorgo, 5(6), 395-405. doi: 10.18512/19806477/rbms.v5n3p395-405

Statistical Analysis System Institute. (2002). Release 8.02.2000. Cary: SAS Institute, Inc.

Storck, L., Cargnelutti, A., Fo , Lopes, S. J., Toebe, M., \& Silveira, T. R. (2009). Duração do subperíodo semeadura-florescimento, crescimento e produtividade de grãos de milho em condições climáticas contrastantes e produtividade de grãos de milho em condições climáticas contrastantes. Revista Brasileira de Milho e Sorgo, 8(1), 27-39. doi: 10.18512/1980-6477/rbms.v8n1p27-39

Tres, T. T., Jobim, C. C., Pinto, R. J. B., Souza, I. L., Neto, Scapim, C. A., \& Silva, M. S. J. (2014). Composição nutricional e digestibilidade "in vitro" de genótipos de milho produzidos em dois anos agrícolas. Semina. Ciências Agrárias, 35(6), 32493262. doi: $10.5433 / 1679-0359$

Tylutki, T. P., Fox, D. G., Durbal, V. M., Tedeschi, L. O., Russell, J. B., Van Amburgh, M. E.,... Pell, A. N. (2008). Cornell net carbohydrate and protein system: A model for precision feeding of dairy cattle. Animal Feed Science and Technology, 143, 174-202. doi: 10.1016/j.anifeedsci.2007.05.010

Van Soest, P. J. (1994). Nutritional ecology of the ruminant. Ithaca: Cornell University Press.

Velho, J. P., Mühlbach, P. R. F., Genro, T. C. M., Barcellos, J. O. J., Braccini, J., Neto, \& Silva, R. S. M. (2014). Modelos matemáticos para ajuste da produção de gases in vitro em diferentes tempos de incubação e cinética ruminal de silagens de milho. Semina. Ciências Agrárias, 35(4), 2531-2540. Suplemento. doi: 10.5433/1679-0359.2014v35n4Supl1p2531

Velho, J. P., Mühlbach, P. R. F., Genro, T. C. M., Sanchez, L. M. B., Nörnberg, J. L., Orqis, M. G., \& Falkenberg, J. R. (2006). Alterações bromatológicas nas silagens de milho submetidas a crescentes tempos de exposição ao ar após "desensilagem". Ciência Rural, 36(3), 916-923. doi: 10.1590/S010384782006000300029 
Velho, J. P., Mühlbach, P. R. F., Nörnberg, J. L., Velho, I. M. P. H., Genro, T. C. M., \& Kessler, J. D. (2007). Composição bromatológica de silagens de milho produzidas com diferentes densidades de compactação. Revista Brasileira de Zootecnia, 36(5), 1532-1538. doi: 10.1590/S151635982007000700011

Vieira, V. C., Martin, T. N., Menezes, L. F. G., Assmann, T., Ortiz, S., Bertoncelli, P.,... Schimitz, T. H. (2013a). Caracterização bromatológica e agronômica de genótipos de milho para produção de silagem. Arquivo Brasileiro de Medicina Veterinária $e$ Zootecnia, 65(3), 847-856. doi: 10.1590/S010209352013000300034.

Vieira, V. C., Martin, T. N., Menezes, L. F. G., Ortiz, S., Bertoncelli, P., \& Storck, L. (2013b). Caracterização bromatológica de silagens de milho de genótipos super precoce. Ciência Rural, 43(11), 1925-1931. doi: $10.1590 / \mathrm{S} 0103-84782013001100001$

Vilela, H. H., Rezende, A. V., Vieira, P. D. F., Andrade, G. A., Evangelista, A. R., \& Almeida, G. B. S. (2008). Valor nutritivo de silagens de milho colhido em diversos estádios Brasileira de maturação. Revista de Zootecnia, 37(7), 1192-1199. doi: 10.1590/ S1516-35982008000700008

Von Pinho, R. G., Vasconcelos, R. D., Borges, I. D., \& Resende, A. D. (2007). Produtividade e qualidade da silagem de milho e sorgo em função da época de semeadura. Bragantia, 66(2), 235-245. doi: 10.1590/ S0006-87052007000200007

Wei, M., Chen, Z., Wei, S., Geng, G., \& Yan, P. (2018). Comparison among methods of effective energy evaluation of corn silage for beef cattle. AsianAustralasian Journal Animal Science, 31(6), 851858. doi: 10.5713/ajas.17.0538
Weiss, W. P. (2019). Effects of feeding diets composed of corn silage and a corn milling product with and without supplemental lysine and methionine to dairy cows. Journal of Dairy Science, 102, 2075-2084. doi: $10.3168 /$ jds.2018-15535

Zardin, P. B., Velho, J. P., Jobim, C. C., Alessio, D. R. M., Haygert-Velho, I. M. P., Conceição, G. M., \& Almeida, P. S. G. (2017). Chemical composition of corn silage produced by scientific studies in Brazil A meta-analysis. Semina. Ciências Agrárias, 38(1), 503-512. doi: 10.5433/1679-0359.2017v38n1p503

Zeoula, L. M., Beleze, J. R. F., Cecato, U., Jobim, C. C., Geron, L. J. V., Maeda, E. M., \& Falcao, A. D. S. (2003a). Avaliação de cinco híbridos de milho (Zea mays, L.). em diferentes estádios de maturação. 3. Composição químico-bromatológica. Revista Brasileira de Zootecnia, 32(3), 556-566. doi: 10.1590/S1516-35982003000300007

Zeoula, L. M., Beleze, J. R. F., Cecato, U., Jobim, C. C., Geron, L. J. V., Prado, O. D., \& Falcão, A. J. S. (2003b). Avaliação de cinco híbridos de milho (Zea mays, L.). em diferentes estádios de maturação. 4b. Digestibilidade da matéria seca, matéria orgânica e fibra em detergente neutro da porção vegetativa e planta inteira. Revista Brasileira de Zootecnia, 32(3), 567-575. doi: 10.1590/S1516-35982003000300008

Zopollatto, M., Nussio, L. G., Mari, L. J., Schmidt, P., Duarte, A. P., \& Mourão, G. B. (2009). Alterações na composição morfológica em função do estádio de maturação em cultivares de milho para produção de silagem. Revista Brasileira de Zootecnia, 38(3), 452-461. doi: 10.1590/S1516-35982009000300008 
